\title{
Evaluation of Dental Eruption of Third Molars in the Length of Mandible
}

\author{
Evaluación de la Erupción Dentaria de los Terceros Molares en Relación a la Longitud de la Mandíbula
}

\author{
*Gilberto de Sousa Filho; ${ }^{* *}$ Adelmar Afonso de Amorim Júnior; \\ **** Carla Cabral dos Santos Accioly Lins \& ${ }^{* * * *}$ Joaquim Celestino da Silva Neto
}

SOUSA FILHO, G.; AMORIM JÚNIOR, A. A.; LINS, C. C. S. A. \& SILVA NETO, J. C. Evaluation of dental eruption of third molars in the length of mandible. Int. J. Morphol., 27(4):1319-1323, 2009.

SUMMARY: The aim of this work was to evaluate the eruption of the third molar teeth in the length of the mandible using the orthodontic documentation obtained between 2005 and 2006 as sampling method, a total of 193 cases of both sexes. The cephalometric analysis and panoramic radiographic studies were chosen from two clinics randomly selected in the city of Recife - Pernambuco - Brazil. It was analyzed the linear size of mandibular bone by the use of McNamara's Cephalometric Analysis, and also the presence or not of dental retention of inferior third molar teeth with the help of panoramic radiographic study, evaluating the commitment of these retentions with the effective length of mandible. The work concluded that when the effective mandibular length is small induces a dental retention of these third molars, mostly the left inferior third molar, which $46.5 \%$ of the cases was observed as retained. However, in $53.8 \%$ of the cases was observed the absence or no-formation of these dental germs for the left inferior third molar and $60 \%$ for the right, showing a big size of the effective length of the mandible exposing that the no-formation of these teeth was not directly related to the lack of space in the dental arch. The study demonstrated that the sexual dimorphism does not influence the eruption of these teeth, however, according to age, was emphasized a dependence concerning about dental eruption, retention or absence of left inferior third molar.

KEY WORDS: Third molar; Mandible; Tooth eruption; Panoramic radiographic study.

\section{INTRODUCTION}

The dental eruption, which exposes the dental elements in the oral cavity, occurs through the subsequent elongation of root, pushing the crown against the subjacent tissue layers until the surface of the gingiva. It is observed that in the evolutive process of the man and due to big changes in feeding habits emphasized by the decrease of physiological activity of maxillary and mandibular bones; the growth is compromised, inducing a decrease of these bones. According to Oliveira et al. (1991) this decrease is an influence for the decrease of number and size of teeth.

To determine the suitable length for the maxillary bone and also the mandibular bone it can be used the McNamara's Cephalometric Analysis which uses craniometric points to gauge, while linear measurement uses cephalometric X-rays in profile which aims to join the points
Co to A for the maxilla and Co to Gn for the mandible. Macnamara Jr. (1984) defined that the suitable value in mixed dentition for the length of maxilla would be $85 \mathrm{~mm}$ and for mandible a value between 105 and $108 \mathrm{~mm}$, in adults these values would be $94 \mathrm{~mm}$ and $120 \mathrm{~mm}$ to $123 \mathrm{~mm}$ in women and $100 \mathrm{~mm}$ and $130 \mathrm{~mm}$ to $133 \mathrm{~mm}$ in men, for the maxilla and the mandible respectively.

One of the biggest doubts in modern Odontology is the real function of the third molar tooth. This tooth, most of times, is formed without enough space for its appearance in the buccal cavity, what is easily evidenced by panoramic X-rays, leading the Dental Surgeon to decide to keep or extract it. However, it's observed that its retention is a common fact and most of times there are no facts which evidence the reason of this dental inclusion.

* DDS, MSc, Assistant Professor of Anatomy, University Federal of Pernambuco, Recife, Pernambuco, Brazil.

** DDS, MSc, PhD, Associate Professor of Anatomy, University Federal of Pernambuco, Recife, Pernambuco, Brazil.

**** DDS, MSc, Assistant Professor of Anatomy, University Federal of Pernambuco, Recife Pernambuco, Brazil.

*****DDS, MSc, PhD, Adjunct Professor of Anatomy, Institute of Biology Science, University of Pernambuco, Recife, Pernambuco, Brazil. 
The panoramic X-rays and cephalometric studies of Macnamara's Analysis can evaluate the commitment of the relation between the space or not for the eruption with the appearance of this dental element in the surface of gingiva. The observation of the appearance of this tooth in the buccal cavity, related to effective length of mandibular bone, can contribute to verify if the bone growth is a determinant fact. An approach concerning about the relation of absence, retention or eruption of dental elements 38 and 48 , objects of this study, verify if the stimulus caused by the functional matrix can be or not factors for the appearance of teeth in oral region.

\section{MATERIAL AND METHOD}

To develop this study, it were analyzed the orthodontic documentations obtained between 2005 and 2006, specially the cephalometric analysis and panoramic X-rays of patients from two private dental clinics from the city of Recife. The orthodontic documentation was randomly selected observing the standards of inclusion: panoramic X-rays of patient at age range higher than 23 years and 11 months of both sexes; Availability of Macnamara's Cephalometric Analysis of these patients. However, it were excluded: Panoramic X-rays which were out of usual standard of revelation and fixation. The orthodontic documentation without the Macnamara's Cephalometric Analysis; patients who were out of the established age range; patients with any pathology in the buccal cavity; patients who were receiving or already received dental or orthopedic treatment.

The sampling had a total of 193 cases, 99 of female sex and 94 of male sex, at an age range that vary from 23 years and 11 months to 36 years and 11 months, in which were observed the standards of inclusion and exclusion previously described.

For this evaluation it was necessary that the data of cephalometric analysis were in accordance with the method of Macnamara, aiming to analyse the effective length of mandible by the linear measurements of points Co-Gn.

To analyze the panoramic X-rays it was used a High intensity Fluorescent Negathoscope and the data were classified in eruptioned teeth, retained teeth and absence of third molars teeth.

\section{RESULTS}

According to Macnamara's Cephalometric Analysis, concerning about the size of the mandible, there was a higher percentage of big $37.8 \%$ followed by small $33.2 \%$ and normal $29.0 \%$.

The absence of teeth 38 is higher in mandible classified as big (53.8\%). In $46.5 \%$ of studied cases was observed the size of mandible small and retention of tooth 38 . About $28.5 \%$ of patients have the size of mandible small, however the teeth 38 was eruptioned (Fig. 1).

In the same way of teeth 38 , the majority of patients $(60 \%)$ with the size of mandible big showed absence of teeth 48. However, $45.5 \%$ of patients with the size of mandible small showed retention of teeth 48 (Fig. 2).

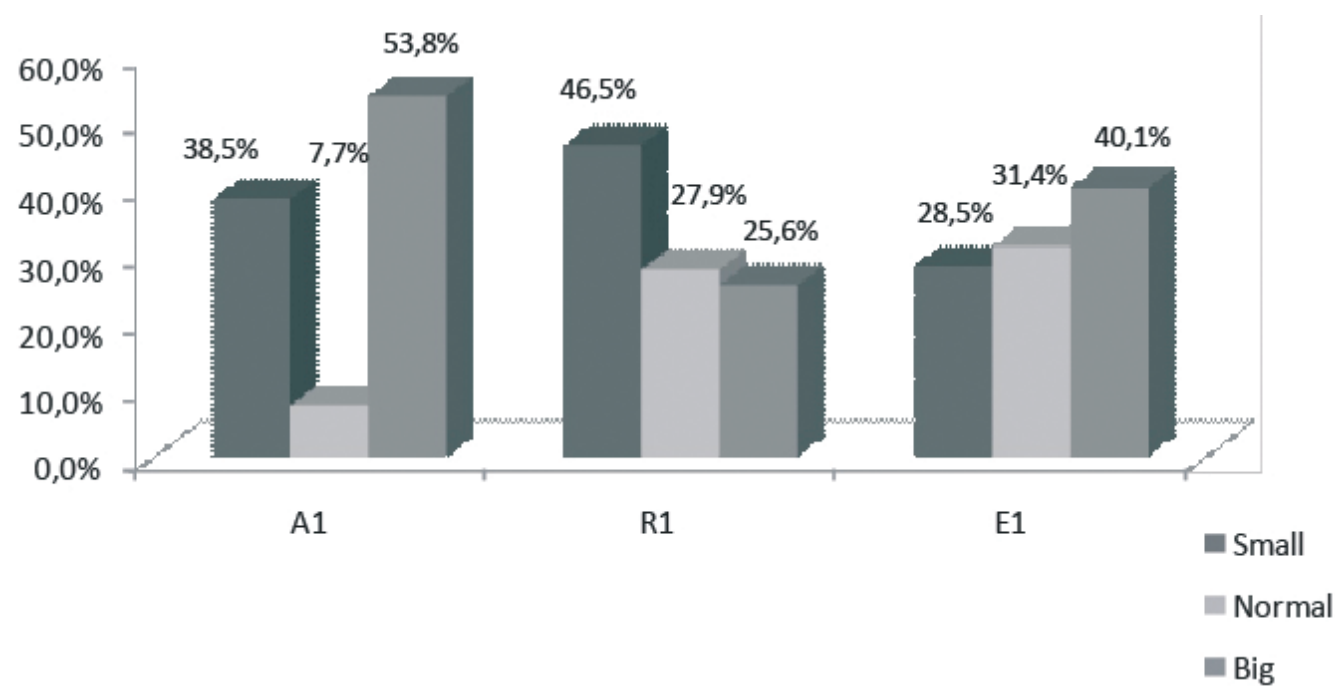

Fig. 1. Relation between the size of the mandible and the absence/retention/ eruption of teeth 38 . 
About $40 \%$ of studied cases showed the size of mandible big and teeth 48 eruptioned.

The absence, retention or eruption of tooth 38 and 48 both showed almost same results when were analyzed with the standard sex, that is, most of it was eruptioned (about $70 \%$ ) independent of sex.
The absence, retention or eruption of tooth 38 and 48 showed almost the same results when were analyzed with the standard age range, that is, about $75.5 \%$ of teeth 38 , was eruptioned. For teeth 48 . 78,6\% was eruptioned, at the studied age range.

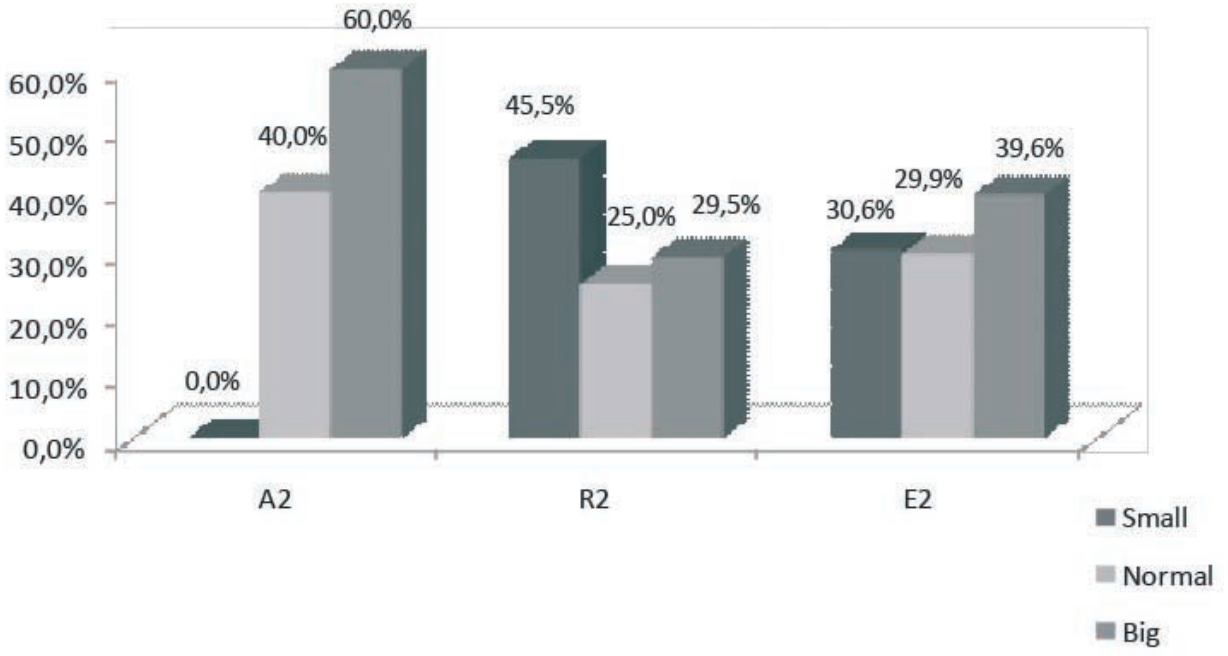

Fig. 2. Relation between the size of the mandible and the absence/ retention/eruption of teeth 48

\section{DISCUSSION}

For the consistent observation of dental retention of third molars, and due to a higher number of registered cases in mandible, according to Forsberg (1988), it was suggested a comparative analysis between the commitment noneruptive of inferior third molar tooth with the linear length of mandible, by panoramic X-rays and Macnamara's Cephalometric Analysis.

It was observed that, according to Macnamara's Cephalometric Analysis for the effective length of mandible, there was a percentage of $37.8 \%$ for the size big, followed for $33.2 \%$ and $29.0 \%$ for the sizes small and normal respectively. The study evidenced that the female sex was the majority of samples, $51.3 \%$ and $41.4 \%$ of patients was at an age range of 24 years to 24 years and 11 months. The aim of this range was to observe a margin of safety concerning about the age of eruption, however, without statistical significance concerning about gender or for eruption on left or right side, according to Otuyemi et al. (1997).

Considering that the size of mandible standardized by Macnamara Jr., it was observed in our results that the size big was higher in female sex, more than $40 \%$, and the size small was higher in male sex $(39.4 \%)$, to the contrary of the data found by Valente et al. (2003), which related that the effective length of mandible evidenced higher values for male samples. However, in this study, the coefficients of variation showed that women vary more than men about $6.5 \%$ in the size of mandible.

Analyzing the effective length of mandible with the absence, retention or eruption of teeth 38 , it was observed that the absence of it is higher in mandibles classified as big $(53.8 \%)$. However, $46.5 \%$ of studied cases showed size of mandible "small" and retention of this dental element emphasizing the studies of Forsberg, for this author there is a direct relation between the total length of alveolar bone arc and the total length of dental arc. However, $28.5 \%$ of cases evidenced mandibles with size small and teeth 38 eruptioned. For this sample, with a level of significance of $10 \%$, the absence, retention and eruption of teeth 38 depend on the size of mandible. In relation to the retention or not of this tooth, according to q-square test, the results were significant, for an error margin of $10 \%$. 
The evaluation of effective length of mandible according to the standard of Macnamara Jr., in relation to absence, retention or eruption of teeth 48 , it was observed that $60 \%$ of patients of sample had size big, however with the absence of this dental element, fact also observed by Brucker \& Stello (2003) concerning about dental absences. However, for the size small it was verified that $45.5 \%$ of studied cases showed retention of this tooth, evidencing a crescent incidence of non-eruption of it, emphasized by Sandhu \& Kaur (2005) and the lack of space between the distal face of second molar and the ascending branch of mandible is the main reason for the high frequency of noneruption of these teeth according to Forsberg, in $40 \%$ of studied cases there was eruption of this tooth, with mandible of size big.

In relation to sex, concerning about sexual dimorphism, it was found that the eruption of tooth 38 and 48 , about $70 \%$, are independent, emphasizing the data found by Yamaoka et al. (1995), so as by Weber et al. (1993) when analyzed the dentoalveolar relations and the skeletal measurements.
The evaluation of absence, retention or eruption of tooth 38 and 48 , in relation to age range, showed independence, since the variation among them were equivalent in the 3 standards, that is, in relation to eruption it was observed $75.5 \%$ for tooth 38 and $78.6 \%$ for teeth 48 , for retention, $19 \%$ and $18 \%$ respectivelly and for absence, $3.6 \%$ for the left inferior third molars and 3\% for the right. The found data are in accordance with the ones of De Salvia et al. (2004) concerning about the regular standard of biological age, so as for Bolanõs et al. (2003) concerning about the similar distribution in the dental development stages at the same age range. However Prieto et al. (2005) affirmed that the dental development of third molars teeth is faster in men than in women varying about nine months.

Observing the absence, retention and eruption in relation to age range, using the Q-square test, was evidenced that there is a dependence of $10 \%$ for teeth 48 , what is the contrary of the data found by Otuyemi et al. which concluded that there were not significant differences for the left of right side.

SOUSA FILHO, G.; AMORIM JÚNIOR, A. A.; LINS, C. C. S. A. \& SILVA NETO, J. C. Evaluación de la erupción dentaria de los terceros molares en relación a la longitud de la mandíbula. Int. J. Morphol., 27(4):1319-1323, 2009.

RESUMEN: El objetivo de la presente investigación fue evaluar la erupción del tercer molar a lo largo de la mandíbula usando documentación de ortodoncia obtenida entre los años 2005 y 2006, en un total de 193 casos de individuos brasileños, adultos, de ambos sexos. El análisis cefalométrico y los estudios radiográficos panorámicos fueron obtenidos de dos clínicas y seleccionados al azar en la ciudad de Recife, Estado de Pernambuco, Brasil. Se analizó el tamaño linear de la mandíbula usando el método cefalómetrico de McNamara, y también la presencia o ausencia de retención dental del tercer molar inferior con la ayuda de radiografías panorámicas, evaluando la relación de esas retenciones, si las hubiere, con la longitud efectiva de la mandíbula. Los resultados muestran que cuando la longitud mandibular efectiva es pequeña induce a retención dental de los terceros molares, siendo en la mayoría de los casos el tercer molar inferior izquierdo, lo cual fue obervado en 46,5 \%. Sin embargo, en el 53,8 \% de los casos se observó ausencia o no formación de los gérmenes dentales del molar mencionado, característica que se encontró en $60 \%$ en el lado derecho, mostrando un gran tamaño de longitud efectiva de la mandíbula, indicando que la no formación de ese molar no fue directamente relacionada a un reducido espacio en el arco dental. El estudio demostró que el dimorfismo sexual no influencia la erupción de ese molar, sin embargo, la variable edad, resaltó una dependencia relacionada con la erupción dental, retención o ausencia del tercer molar inferior izquierdo.

PALABRAS CLAVE: Tercer molar; Mandíbula; Erupción dentaria; Radiografías panorámicas.

\section{REFERENCES}

Bolaños, M. V.; Moussa, H.; Manrique, M.C. \&Bolaños, M. J. Radiographic Evaluation of third molar development in Spanish children and young people. Forensic Science Inter., 133:212-9, 2003.

Brucker MJ, Stello D. Avaliação da prevalência de agenesias dentárias de indivíduos com mais de 9 anos de idade da população do Rio Grande do Sul através de radiografias panorâmicas. Rev. OdontoCiência,18(42):323-30, 2003.
De Salvia A, Calzetta C, Orrico M, De Leo D. Third mandibular molar radiological development as na indicator of chronological age in a european population. Forensic Scinece Inter, 146:9-12, 2004.

Forsberg, C. M. Tooth size, Spacing, and Crowding in relation to eruption or impaction of third molars. Am Journal Orthodontic Dentofacial Orthopedic, 94(1):57$62,1988$. 
Mcnamara, J. R. J.A. A method of cephalometric evaluation. Am. J. Orthodontics, 86(6):449-69, 1984.

Oliveira, A. G.; Consolaro, A. \& Henriques, J. F. C. Relação entre a anodontia parcial e os dentes permanentes de brasileiros: Associação de sua ocorrência com o tamanho mesiodistal das coroas dentárias. Rev. de Odontologia da Universidade de São Paulo, 5(1):7-14, 1991.

Otuyemi, O. D.; Ugboko, V. I.; Ndukwe, K. C. \& AdekoyaSofowora, C. A. Eruption times of third molars in young rural Nigerians. Int. Dental J., 47:266-70, 1997.

Prieto. J. L.; Barbería, E.; Ortega, R. \& Maganã, C. Evaluation of chrnological age based on third molar development in the spanish population. Int. J. Legal Medicine, 119:349-54, 2005.

Sandhu, S \& Kaur, T. Radiographic evaluation of the status of third molars in Asian-Indian students. J. of Oral and Maxillofacial Surgery, 63: 640-5, 2005.

Valente, R. O. H. \& Oliveira, M. G.Valores normativos e dimorfismo sexual em perfis esteticamente agradáveis, através das análises cefalométricas computadorizadas (Ricketts e Macnamara). Pesquisa Odontológica Brasileira, 17(1): 29-34, 2003.

Weber, J. S. U.; Trotman, C.; Macnamara Jr. J. A. \& Behrents, R. G. Sexual dimorphism in normal craniofacial growth. The Angle Orthodontist, 63(1):47-56, 1993.

Yamaoka, M. Influence of adjacent teeth on impacted third molars in the upper and lower jaws. Australian Dental J. 40(4):233-5, 2995.

\section{Correspondence to:}

Adelmar Afonso de Amorim Júnior Anatomy

University Federal of Pernambuco,

Recife,

Pernambuco

BRAZIL

Email: adelmarjr@yahoo.com

Received: 20-02-2009

Accepted: 08-09-2009 
